\title{
Life cycle of Calanus hyperboreus in the lower St. Lawrence Estuary and its relationship to local environmental conditions
}

\author{
Stéphane Plourde ${ }^{1,4, *}$, Pierre Joly ${ }^{2}$, Jeffrey A. Runge ${ }^{2,5}{ }^{,}$Julian Dodson $^{1}$, Bruno Zakardjian ${ }^{3}$ \\ ${ }^{1}$ Département de Biologie, Université Laval, Pavillon Vachon, Ste-Foy, Québec G1K 7P4, Canada \\ ${ }^{2}$ Fisheries and Oceans, Maurice-Lamontagne Institute, Division of Ocean Sciences, 850 Route de la Mer, Mont-Joli, \\ Québec G5H 3Z4, Canada \\ ${ }^{3}$ Institut des Sciences de la Mer à Rimouski (ISMER), 310 Allée des Urselines, Rimouski, Québec G5L 3A1, Canada
}

${ }^{4}$ Present address: Oceanic Science Division, Institute Maurice-Lamontagne, Fisheries and Oceans Canada, 850 Route de la Mer, C.P. 1000, Mont-Joli, Québec G5H 3Z4, Canada

${ }^{5}$ Present address: Ocean Process Analysis Laboratory, 142 Morse Hall, University of New Hampshire, Durham, New Hampshire 03824, USA

\begin{abstract}
We studied the life cycle of Calanus hyperboreus in the lower St. Lawrence Estuary (LSLE) using (1) C. hyperboreus population-stage abundance and body size data, and time series of chl a biomass, collected between 1991 and 1998 at a monitoring station, (2) observations of the seasonal pattern in day/night vertical distribution of $C$. hyperboreus in the LSLE and the adjacent NW Gulf of St. Lawrence (GSL) and (3) observations of long-term C. hyperboreus egg production conducted during winter. Total abundance (Stages C1 to C6f) was similar among years, and stage composition (Stages C4, C5, and C6f) was constant in summer and autumn of each year. However, the abundance of Stages C1 to C3 in May and the stage structure during the summer-autumn period showed significant interannual variation. The seasonal pattern in vertical distribution and body weight suggests that the C. hyperboreus population overwinters in the 200 to $300 \mathrm{~m}$ water layer from July to April with the ontogenetic ascent and descent mainly occurring in late April/early May and July, respectively. We propose a 3 yr life cycle for adult females (Stage C6f), with the main reproductive event occurring during the second year of life. C. hyperboreus females initiate gonad maturation in early December and reproduce until late March, 3 to 6 mo prior to the onset of the phytoplankton bloom in the LSLE. Total fecundity of Stage C6f was inversely related to respiration but not to female body size. The interaction between the timing of reproduction and the peak in freshwater runoff likely promote the export of the new cohort in spring and the upstream advection of overwintering animals from the adjacent NW GSL in early summer. This interaction apparently precludes the evolution of a population synchronized with the seasonality in biological and physical conditions in the LSLE. We hypothesize that the surface circulation pattern in the LSLE and biological and physical conditions in the NW GSL in spring likely control the interannual variations in abundance of Stages $\mathrm{C} 1$ to $\mathrm{C} 3$ in spring, and in overwintering stage structure.
\end{abstract}

KEY WORDS: Calanus hyperboreus $\cdot$ Life cycle $\cdot$ Reproduction $\cdot$ Estuary $\cdot$ Circulation Resale or republication not permitted without written consent of the publisher

\section{INTRODUCTION}

Calanus hyperboreus is a large calanoid copepod inhabiting arctic waters and areas of the subarctic Atlantic under the influence of southward advection of water of arctic origins (Conover 1988). In the NW Atlantic,
C. hyperboreus is an important contributor to the zooplankton community in deep regions of the Gulf of St. Lawrence, Gulf of Maine and Scotian Shelf (Conover 1988, Runge \& Simard 1990, Sameoto \& Herman 1990).

The reproductive strategy of Calanus hyperboreus is well adapted to the extreme seasonal regimes of tem- 
perature and phytoplankton production at high latitudes (Conover 1988, Conover \& Huntley 1991). Lipid-rich females (Stage C6f) produce eggs during overwintering from their body energy reserves (Hirche \& Niehoff 1996). Eggs and naupliar stages slowly develop using their energy reserves as they ascend to the surface waters, where feeding is initiated either on ice-algal (in ice covered regions) and/or pelagic phytoplankton blooms (Conover 1988). Depending on temperature and food regimes, the new cohort achieves development and accumulates lipids for overwintering in Stages C3 to C5 (Conover 1988). A 2 to $4 \mathrm{yr}$ life cycle is observed over most of its geographical distribution. In warmer regions of the north Atlantic, such as the Gulf of Maine and Norwegian Sea, an annual life cycle has been proposed (Conover 1988, Hirche 1997). Development from Stage C5 to adult stages likely occurs during the overwintering period, but the timing of molting in other copepodid stages is ambiguous (Hirche 1997). Iteroparity in Stage C6f is also proposed, but strong evidence is lacking (Conover \& Siferd 1993).

The lower St. Lawrence Estuary (LSLE) and the Gulf of St. Lawrence (GSL) form a semi-enclosed sea covered by ice from January to March. This sea has a cold temperature regime in comparison to the adjacent NW Atlantic, Scotia Shelf and Gulf of Maine (Loder et al. 1998). The region is characterized by the presence of a permanent cold intermediate layer (CIL) (30 to $125 \mathrm{~m}$ in summer, minimum temperature $-1^{\circ} \mathrm{C}$ ) formed by the combined effects of advection of arctic water from the Labrador Current through the Strait of Belle Isle and the autumn-winter cooling and mixing (Gilbert \& Pettigrew 1997). This cold water mass overlays a warmer and more saline deep water layer $\left(5^{\circ} \mathrm{C}\right.$, 33 to 34 PSU) mainly formed by the mixing of deep Atlantic and Labrador Sea water at the margin of the continental shelf and advected in the Laurentian Channel, a deep marine valley extending to the head of the LSLE (Bugden 1991). Important interannual and decadal variations in ice coverage and in temperature of surface, CIL and deep layers have been observed in the region (Bugden 1991, Koutitonsky \& Bugden 1991, Gilbert \& Pettigrew 1997). The general circulation pattern is mainly driven by a freshwater outflow in the 0 to $50 \mathrm{~m}$ surface layer that is compensated by the upward advection of underlying CIL and Atlantic water masses
(Fig. 1) (Koutitonsky \& Bugden 1991). The seasonal and spatial heterogeneity in physical conditions driven by surface circulation largely determine the spatiotemporal pattern in phyto- and zooplankton community structure and abundance in the LSLE (Therriault \& Levasseur 1985, Zakardjian et al. 2000, Plourde et al. 2002). Despite the major contribution of Calanus hyperboreus to the zooplankton community in the LSLE-GSL region, little is known about either its life cycle or the environmental parameters controlling its population dynamics in the region (Runge \& Simard 1990, de Lafontaine et al. 1991, Plourde et al. 2002).

Plourde et al. (2001) proposed that the population dynamics of the sub-arctic Calanus finmarchicus in the LSLE results from the superposition of 2 components of the overwintering stock: (1) an 'early' component mainly exported in spring and renewed by the advection of animals from the NW GSL through the deep residual upstream currents, and (2) a 'late' component synchronized with the summer environmental conditions (phytoplankton bloom, high temperature) favoring its local development and maintenance. Given the general life-cycle strategy of Calanus hyperboreus, we hypothetize that the population of C. hyperboreus would show a response to the environmental conditions in the LSLE similar to the 'early' component of the 
C. finmarchicus population, i.e. a massive export of the population in spring during the main period of freshwater discharge and renewal by upstream advection of deep-dwelling overwintering animals from the adjacent NW GSL.

This study seeks to test this general hypothesis by describing the timing of key events in the life cycle of Calanus hyperboreus in relation to the particular seasonal and interannual variations in the biological and physical environment in the LSLE. First, we describe the life cycle of $C$. hyperboreus based on a time series of stage abundance $(5 \mathrm{yr}$ ) and body size ( $8 \mathrm{yr}$ ) from spring to late autumn, seasonal vertical distribution patterns in the LSLE and NW GSL, and laboratory-generated egg production patterns during winter. Second, we examine the effect of food and variations in temperature on the reproduction of the species. From these observations, we propose mechanisms for the control of the population dynamics of $C$. hyperboreus in the LSLE.

\section{MATERIALS AND METHODS}

Field sampling. Sampling was carried out between 1991 and 1998 at a station located $16 \mathrm{~km}$ north of Rimouski in the deep $(330 \mathrm{~m})$ Laurentian Channel (Fig. 1). The station was visited at various time intervals from late April (1991 and 1997) to mid-December (1991 and 1996) (total of 185 visits). The basic protocol consisted of an STD (Applied Microsystems STD-12) profile from the surface to $250 \mathrm{~m}$ depth, collection of water with 51 Niskin bottles at 8 depths $(0,5,10,15,20$, 25,35 and $50 \mathrm{~m}$ ) and collection of zooplankton with a $1 \mathrm{~m}$ diameter, $333 \mu \mathrm{m}$ mesh ring net. Occasionally, CTD and chl a measurements were not taken. The plankton net was fitted with a restricted-flow cod end and a TSK flowmeter. It was towed at $<30 \mathrm{~m} \mathrm{~min}^{-1}$ from $250 \mathrm{~m}$ to the surface, and the catch was immediately transferred into 41 jars filled with $0.2 \mu \mathrm{m}$ filtered seawater (FSW). Additionally, a $1 \mathrm{~m}$ diameter, $73 \mu \mathrm{m}$ mesh ring net was towed from $50 \mathrm{~m}$ to the surface (with the exception of 1995) to sample early development stages. Samples were consistently collected between 10:00 and 12:00 $\mathrm{h}$; water samples (stored in dark bottles) and zooplankton were maintained at 5 to $6^{\circ} \mathrm{C}$ in coolers during transport to the laboratory at the Maurice-Lamontagne Institute (Mont-Joli, Québec). The laboratory analyses (filtration, copepod sorting) typically began between 14:00 and 15:00 h.

RIVSUM is an index of the freshwater discharge in the LSLE (Budgen et al. 1982). Monthly means data $\left(\mathrm{m}^{3} \mathrm{~s}^{-1}\right)$ were obtained from D. Gilbert, MauriceLamontagne Institute, Mont-Joli, Canada.

Stratified samples using the multinet sampler BIONESS were collected during cruises of opportunity in
March 1992, late May-early June 1998, late Juneearly July 1997 and September 1994 to 1998. Three stations in the NW GSL and 8 stations in the LSLE were sampled once or on several occasions (Fig. 1). Usually 2 tows were made for each day and night collection. The $1 \mathrm{~m}^{2}$ BIONESS was towed at 1.5 to 2.0 knots and the water column was divided into 8 to 9 strata $(0-25$, $25-50,50-75,75-100,100-150,150-200,200-250$, $250-300,300 \mathrm{~m}$ to bottom). Both 250 and $333 \mu \mathrm{m}$ meshsize nets were used for the upper 4 depth layers $(0$ to $100 \mathrm{~m}$ ) and only $333 \mu \mathrm{m}$ mesh-size nets for deeper layers $(>100 \mathrm{~m})$. Results are presented as the average, stage-specific vertical distribution of all tows made during day or night during different seasons in the 2 regions.

Laboratory analyses. Chl a, live animal sorting, and sample analysis: Duplicate 250 to $750 \mathrm{ml}$ subsamples from each water bottle were filtered on GF/F filters. The filters were placed in $95 \%$ acetone and chl a was extracted at $5^{\circ} \mathrm{C}$ for 16 to $24 \mathrm{~h}$. Extracts were analyzed on a Turner Designs Model 112 fluorometer, and chl a concentrations were calculated according to Parsons et al. (1984) and integrated over the depth sampled (0 to $50 \mathrm{~m}$ ). Within 1 to $3 \mathrm{~h}$ of arrival, Calanus hyperboreus development stages used for measurement of prosome length, dry weight and carbon/nitrogen weight were sorted under a dissecting microscope at 6 to $12 \times$ magnification from the diluted zooplankton catch. Care was taken to maintain the zooplankton at 5 to $6^{\circ} \mathrm{C}$ during sorting, with ice in the transport coolers. The remainder of the zooplankton catch was preserved in $4 \%$ formaldehyde for analysis of composition and abundance.

The formalin-preserved samples were rinsed in tap water, and $10 \mathrm{ml}$ aliquots were taken with a Stempel pipette. Species and stage composition were determined under a dissecting microscope at 6 to $50 \times$ magnification. Between 300 and 600 individuals were identified in each sample, and no less that $1 / 100$ of the original sample was analyzed. The copepodid Stages $\mathrm{C} 1$ to $\mathrm{C} 3$ Calanus hyperboreus were distinguished from C. glacialis based on body size (Unstad \& Tande 1991). Copepodid Stages $C 1$ to $C 5$ were grouped in the analysis in 1991, 1992 and 1993. The 1994 to 1998 time series were therefore used to describe chl $a$ and C. hyperboreus population stage abundance and structure.

Body size: Prosome length, dry weight, and carbon/ nitrogen content of Calanus hyperboreus Stages C4, $\mathrm{C} 5$ and C6f were measured on several occasions between 1991 and 1999. Animals were quickly sorted, prosome length measured at 12 to $25 \times$ magnification, rinsed in distilled water and individually placed in a CHN tin boat pre-weighed with a CANLAB electronic balance. Samples were stored in a desiccator at $70^{\circ} \mathrm{C}$ and weighted after 24 and $48 \mathrm{~h}$. Carbon/nitrogen analyses were made on a Perkins CHN Elemental Analyser. 
Egg production experiments: Long-term egg production experiments were conducted on 3 different occasions between 1991 and 1999. The first experiment was designed to describe the natural reproductive cycle of Calanus hyperboreus and to test the hypothesis that reproduction is independent of food supply. From a plankton tow on 18 December 1991, 34 C. hyperboreus Stage C6f were sorted and individually incubated in $150 \mathrm{ml}$ egg separators fitted with $333 \mu \mathrm{m}$ mesh screens, and immersed in $250 \mathrm{ml}$ containers filled with filtered seawater (FSW) at 0 to $1^{\circ} \mathrm{C}$ in the dark. Stage C6f were transferred to new containers with fresh FSW every 5 to $7 \mathrm{~d}$ until the start of egg counts on 8 January 1992. The animals were then separated into 2 groups; the first was incubated in FSW and the second fed ad libitum with the diatom Thalassosira weissflogii. During the first $40 \mathrm{~d}$ of the experiment (until 17 February 1992), animals were transferred to new containers every 1 to $4 \mathrm{~d}$. The state of gonad maturation was determined according to Hirche \& Neihoff (1996) and released eggs were counted. Thereafter, we counted eggs and nauplii 4 times $(10,20,24$ and 27 March 1992). Because of these infrequent counts, we considered the first $40 \mathrm{~d}$ of the experiment in the statistical comparison of clutch size, spawning interval and egg production rate among experimental groups (food, temperature). All data were used to estimate total fecundity.

The main objective of the 1998 experiment was to evaluate the effect of temperature on the egg production and energy budget of Calanus hyperboreus. On 13 October 1998, Stage C6f were captured, sorted and stored at 5 to $6^{\circ} \mathrm{C}$ in FSW in large 151 containers. On the following day, prosome length and oil-sac area of 138 Stage C6f were measured at $12 \times$ magnification under a dissecting microscope coupled to an image analysis system (BIO-QUANT). We used 48 Stage C6f for the initial measurements of dry and carbon/nitrogen weight. The remaining $90 \mathrm{C} 6 \mathrm{f}$ were incubated in $50 \mathrm{ml}$ petri dishes filled with FSW and allocated to 3 treatments $\left(0,4,8^{\circ} \mathrm{C}\right)$ encompassing the long-term variations in the temperature of the deep-water layer (Budgen 1991). The prosome length, oil sac and carbon/nitrogen measurements were used to estimate the initial body size of Stage C6f in the egg production experiment. The determination of the state of gonad development, egg counts and transfers of the animals to new containers filled with fresh FSW were performed every 2 to $3 \mathrm{~d}$. Unfortunately, the experiment was terminated on 27 November because of an incubator malfunction. Nevertheless, 11 Stage C6f matured and laid $>3$ clutches at $8^{\circ} \mathrm{C}$. These data were used to compare the clutch size, spawning interval and egg production among different experimental groups (temperature).
We conducted an additional experiment in 1999 to compensate for the lost data in 1998. Stage C6f were captured and sorted on 15 October and then transported in $4 \mathrm{l}$ jars filled with FSW in coolers at 2 to $3^{\circ} \mathrm{C}$ to Laval University, Québec City. On 17 October, we sorted, respectively, 30 and 50 Stage C6f for measurement of the initial body size and for the egg production experiment at $4.5^{\circ} \mathrm{C}$, following the 1998 procedure. We assessed the state of gonad maturity and egg production every 2 to 4 d from 8 November 1999 to 29 February 2000 . We closely checked animals for oil-sac depletion and arrest of gonad maturation. Based on these observations, we used the spent females (36 out of 50) for the measurement of the final body size. We considered the first $72 \mathrm{~d}$ of the experiment for the comparison of clutch size, spawning interval and egg production rate among different temperature regimes.

Energy budget. We estimated the energy budget of Calanus hyperboreus Stage C6f using the following
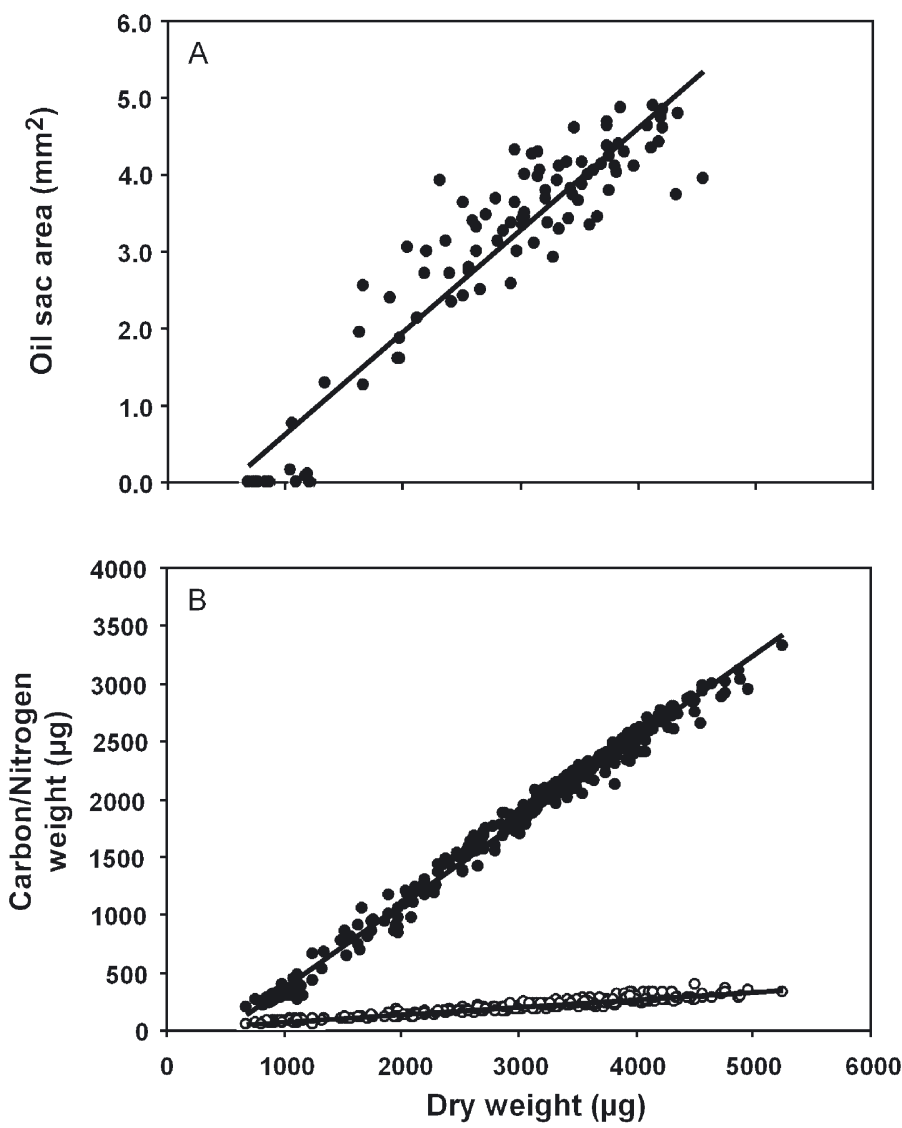

Fig. 2. Calanus hyperboreus. Body size of Stage C6f in the lower St. Lawrence Estuary (LSLE). (A) Oil sac area $\left(\mathrm{mm}^{2}\right)$ and (B) carbon $(\mu \mathrm{g})(\bullet)$ and nitrogen $(\mu \mathrm{g})(O)$ in relation to dry weight $(\mu \mathrm{g})$ measured at the start and the end of egg production experiments and at sampling stations. Each point represents an individual measurement. Data fit to a linear regression model where (A) $y=0.0013 x-0.68, R^{2}=0.87$. (B) Carbon: $y=0.72 x-355.25, \mathrm{R}^{2}=0.99$; nitrogen: $y=0.06 x+9.90, \mathrm{R}^{2}=0.92$ 
variables: initial and final body carbon $(\mu \mathrm{g})$, total egg production (eggs female ${ }^{-1}$ ) and individual spawning duration (d). The initial body carbon was estimated from the relationships between the oil sac area, dry weight and body carbon (Fig. 2). We used an egg carbon content of $0.84 \mu \mathrm{g}$ to transform total egg production to body carbon weight $(\mu \mathrm{g})$ (Huntley \& Lopez 1992). We considered the number of days between the time of initial gonad maturation and final body weight measurement as the spawning duration (d). The difference between the losses in total body carbon $(\mu \mathrm{g})$ (initial - final body carbon) and total egg production $(\mu \mathrm{g})$ was divided by the spawning duration (d) to estimate the weight-specific respiration rate (\% body carbon $\mathrm{d}^{-1}$ ).

\section{RESULTS}

\section{Seasonal and interannual variations in abundance and stage structure}

Although sampling frequency was sparse during the May-June period, seasonal patterns nevertheless emerged (Fig. 3). Total abundance, averaged biweekly, tended to decrease in spring during the period of high freshwater runoff (Fig. 3A,D). In most years, total abundance then increased in late June and early July, despite notable differences in monthly freshwater runoff, surface temperature $\left(4.5\right.$ to $\left.6.5^{\circ} \mathrm{C}\right)$, salinity (23 to 28 PSU) and bi-weekly chl a biomass (30 to $250 \mathrm{mg} \mathrm{chl} \mathrm{a} \mathrm{m}^{-2}$ ) in May, June and July (Fig. 3A-D).

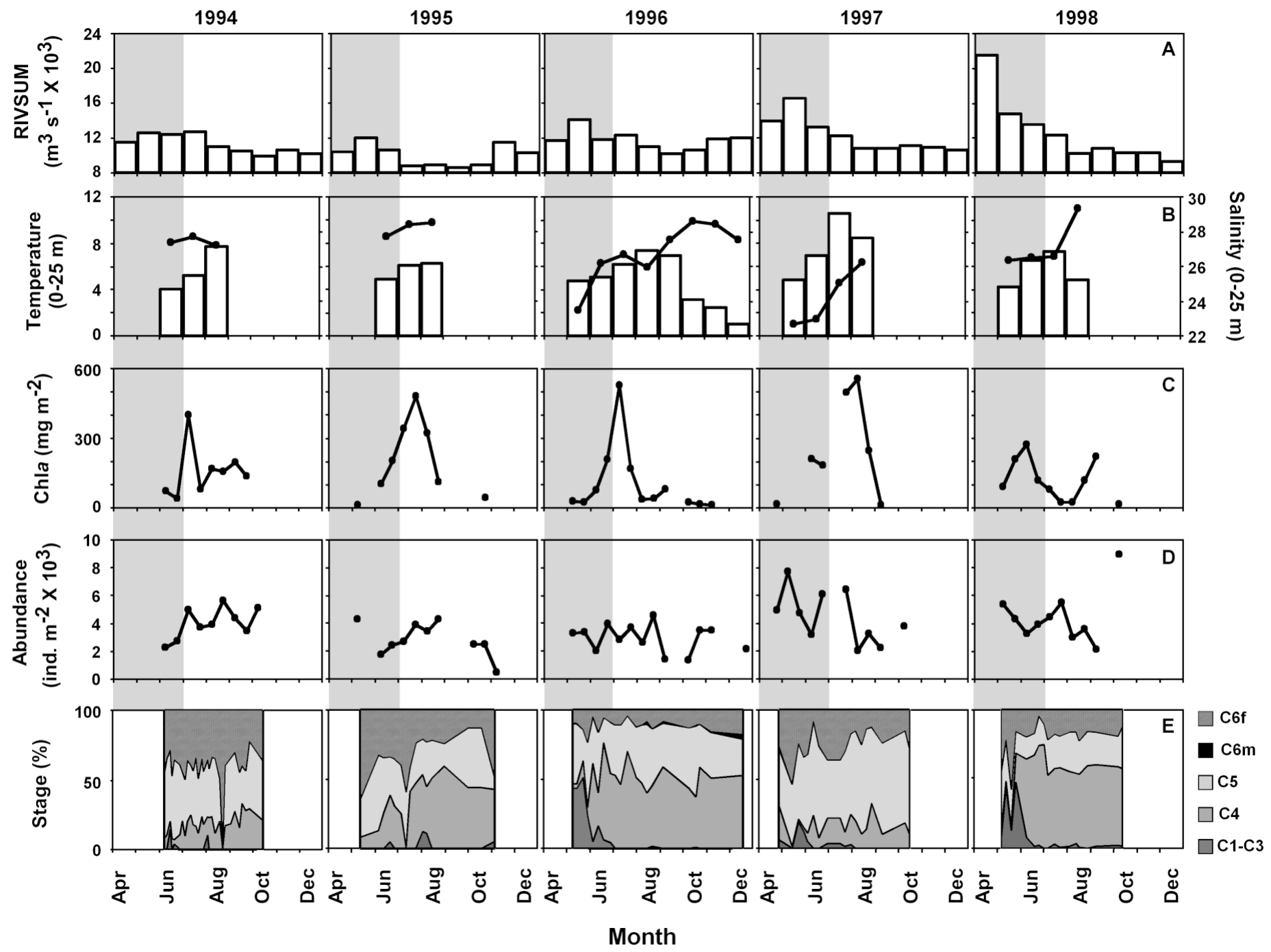

Fig. 3. Annual time series (1994 to 1998) of environmental conditions and population dynamics of Calanus hyperboreus in the central lower St. Lawrence Estuary (LSLE). Monthly average of (A) freshwater runoff (RIVSUM) and (B) temperature (bars) and salinity (lines) in the surface layer $(0$ to $25 \mathrm{~m})$. (C) Integrated total chl a $\left(\mathrm{mg} \mathrm{m}^{-2}\right)$ standing stock for the upper $50 \mathrm{~m}$ of the water column. (D) Bi-weekly aver age in total abundance (Stages C1 to C6f) (ind. $\mathrm{m}^{-2} \times 10^{3}$ ). (E) Population stage composition (\%). 
A decrease in total abundance in late summer and early autumn was common. We observed no significant interannual difference in total abundance from early June to early October (the period covered in each year) (ANOVA, $\mathrm{p}>0.05$ ).

No Calanus hyperboreus nauplii were observed over the entire sampling period. A high abundance of early copepodid Stages C1 to C3 occurred in years of moderate (1996) and high (1998) spring freshwater runoff, surface salinity and chl a biomass (Fig. 3A). The abundance of Stage C4, which likely developed from Stage C1 to C3 in June, was relatively high in 1996 and 1998, but low in the other years. Although the within-year stage structure was constant for the period July to December (ANOVA on ranks of monthly means, $\mathrm{p}>0.05$ ), there was significant interannual variation in the relative abundance of Stages C4, C5 and C6f (ANOVA on ranks, $\mathrm{p}<0.001$ ). Stage $\mathrm{C} 4$ dominated the population in 1995, 1996, and 1998, whereas Stage C5 dominated in 1994 and 1997. Years of high Stage C4 relative abundance occurred after high Stage C1 to C3 contributions in spring of 1996 and 1998, but not in 1995. Stage C6f represented 40 and $30 \%$ of the population in 1994 and 1995, respectively, but no more than $20 \%$ in 1996, 1997 and 1998. Adult males were rare and infrequently observed from August to December.

\section{Average seasonal pattern in abundance and body size of Stages C4, C5 and C6f}

We used monthly RIVSUM values, the bi-weekly averaged abundance of Calanus hyperboreus Stages C4 to C6f from 1994 to 1998, and a composite of all prosome length and dry weight data to depict the general seasonal pattern in the life cycle of $C$. hyperboreus in the LSLE. We distinguished 3 periods using the chl a biomass data (Fig. 4): (1) a pre-bloom period when chl $a$ was $<50 \mathrm{mg} \mathrm{m}^{-2}$, (2) an onset period when chl a values of $>50 \mathrm{mg} \mathrm{m}^{-2}$ were first observed, and (3) a main and post-bloom period.

The dry weight of Calanus hyperboreus Stages C4, C5 and C6f showed a marked seasonal pattern, without corresponding changes in prosome length, that was associated with the seasonal variation in their abundance and in phytoplankton biomass (Fig. 4). The minimum dry weight of the different development stages was observed during the period of high freshwater runoff, lower abundance and pre-bloom conditions in April and May (Fig. 4). Dry weight of Stages C4, C5 and C6f significantly increased over the period of the onset of the bloom to reach maximal values in early July (ANOVA on ranks, $p<0.05$ ), which also corresponded to their increase in abundance. Thereafter, body size was constant over the main and post-bloom

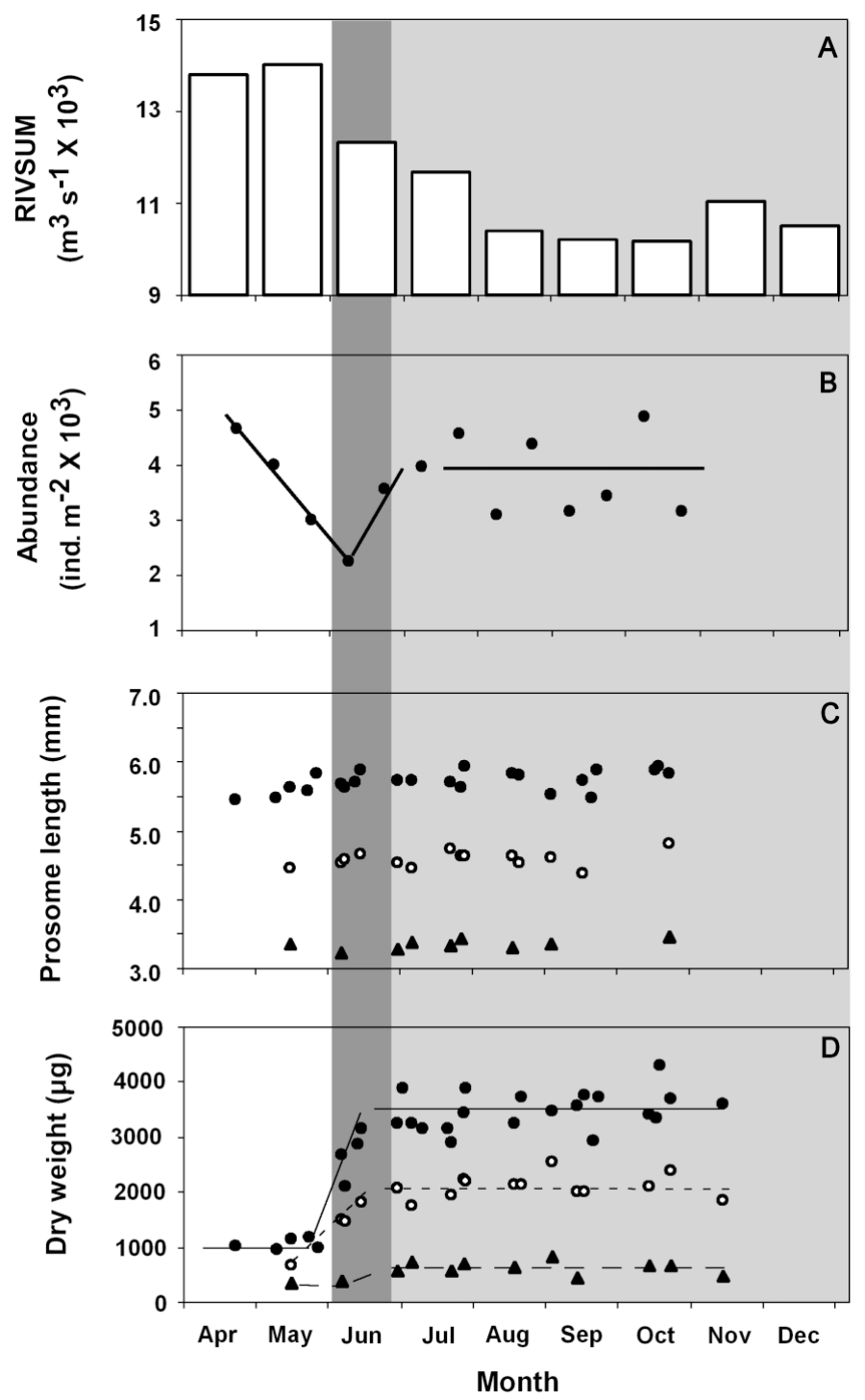

Fig. 4. General seasonal pattern in freshwater runoff, Calanus hyperboreus late copepodid-stage abundance (1994 to 1998) and body size (1991 to 1998) in the lower St. Lawrence Estuary (LSLE). (A) Monthly average of the freshwater runoff (RIVSUM). (B) Biweekly average in Stage C4 to C6f abundance. Composite of (C) mean prosome length $(\mathrm{mm})$ and $(\mathrm{D})$ mean body dry weight $(\mu \mathrm{g})$ of Stages C6f $(\bullet)$, C5 $(0)$ and C4 (4) on each sampling occasion between 1991 and 1998 in the LSLE. White area: pre-bloom period (chl $a<50 \mathrm{mg} \mathrm{m}^{-2}$ ); dark gray area: period of onset of the phytoplankton bloom (period of first chl a $>50 \mathrm{mg} \mathrm{m}^{-2}$ ): light gray area: main and post-bloom period (mean chl a: $190 \mathrm{mg} \mathrm{m}^{-2}$ ). Each point represents the average of 12 to 24 individual measurements. Regressions fitted by eye

period (ANOVA on ranks, $p>0.05$ ). The difference in dry weight between the pre-bloom and the main and post-bloom periods represented an increase of $70 \%$ in body weight of Stages C6f and C5, and 50\% in Stage C4. The dry weight in Stages C4 and C5 during the main and post-bloom period varied significantly among 

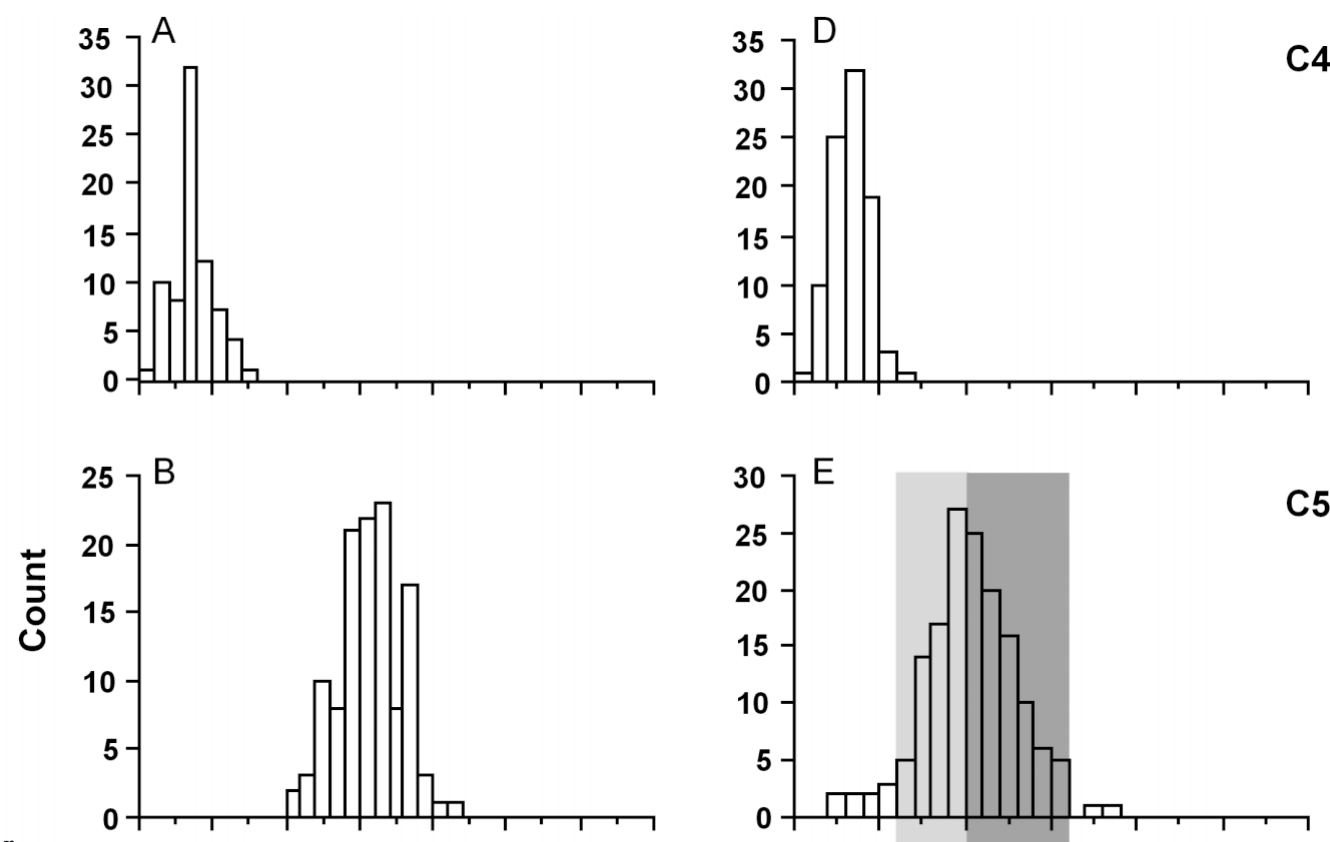

Fig 5. Calanus hyperboreus. Frequency distribution of individual prosome length (mm) (left panels) and dry weight (right panels) of Stage C4 $(\mathrm{A}, \mathrm{D}), \mathrm{C} 5$ $(\mathrm{B}, \mathrm{E})$ and $\mathrm{C} 6 \mathrm{f}(\mathrm{C}, \mathrm{F})$ measured during the main and post-bloom period in the lower St. Lawrence Estuary (LSLE). Overlap between the lower and the upper $50 \%$ of Stages C5 and C6f dry weight are denoted by the light and dark gray areas, respectively
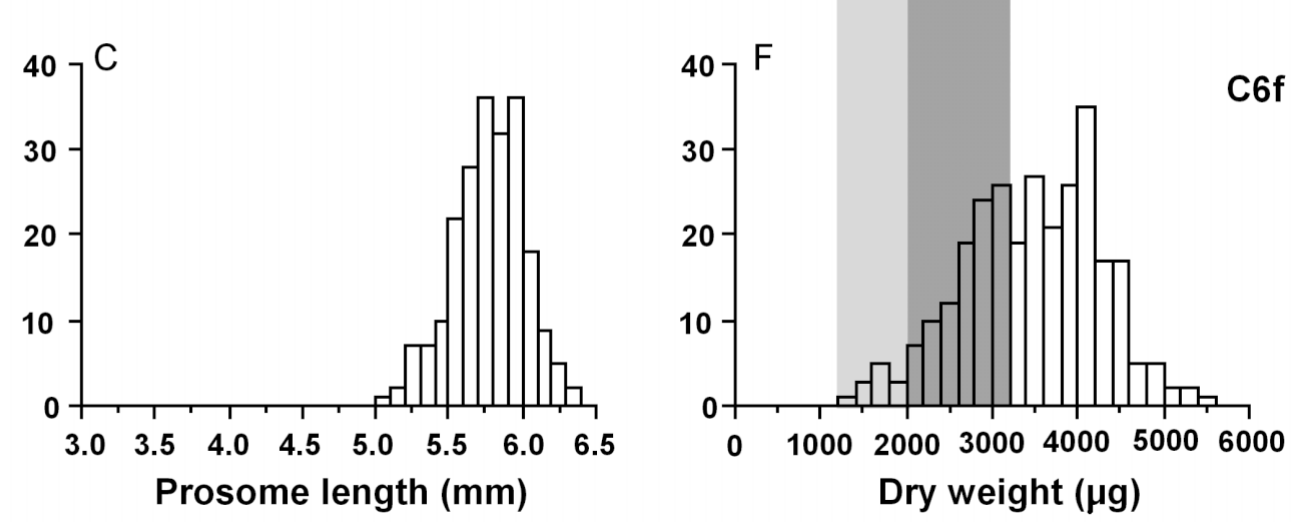

years (ANOVA on ranks, p < 0.05) despite no such differences in prosome length. Stage C4 individuals were heavier in $1995(731 \mu \mathrm{g})$ than in $1996(579 \mu \mathrm{g})$ whereas the C5 were significantly smaller in 1994 $(1916 \mu \mathrm{g})$ than in $1995(2316 \mu \mathrm{g})$ and $1996(2017 \mu \mathrm{g})$. No significant interannual differences were observed in prosome length and dry weight in C6f.

The frequency distributions of prosome length and dry weight in Stages C4, C5 and C6f during the main and post-bloom period (July to November) are shown in Fig. 5. There was no overlap in prosome length among the different development stages (Fig. 5A-C), whereas very few Stage C5 showed a dry weight similar to the Stage C4 (Fig. 5D-E). However, the dry weight in Stages C5 and C6f showed a marked overlap (Fig. 5E,F). A large proportion (34\%) of the dry weight in Stage C6f was in the range of the upper half of C5 dry weight distribution, whereas only $4 \%$ of Stage C6f weighed less than $2000 \mu \mathrm{g}$, the lower half of C5 dry weight distribution.

\section{Seasonal pattern in vertical distribution}

Calanus hyperboreus exhibited a strong ontogenetic vertical migration and evidence for a different timing in the LSLE and the NW GSL (Fig. 6). In March, the bulk ( $80 \%$ ) of copepodid Stages C4, C5 and C6f in the LSLE was located below $150 \mathrm{~m}$ during both day and night. In the LSLE in late May-early June, the whole population occupied the top $150 \mathrm{~m}$ of the water column, with Stages C3 and C4 mainly located between 25 and $125 \mathrm{~m}$ without marked diel vertical migration. The older stages showed a pronounced diel vertical migration, moving from the 50 to $125 \mathrm{~m}$ layer during daylight to $0-75 \mathrm{~m}$ and 0-50 $\mathrm{m}$ at night for Stages C5 and C6f, respectively. The situation was different in the NW GSL during the same period. All Stage C6f were located below $150 \mathrm{~m}$ with no sign of vertical migration, whereas Stages C3, C4 and C5 showed a broad-spread distribution; a large part of the population migrated on a daily basis within the top $125 \mathrm{~m}$ of the water column, whereas the rest of the pop- 
ulation occupied the 125 to $300 \mathrm{~m}$ depth layer. One month later (late June-early July), the C. hyperboreus population in the LSLE exhibited a somewhat similar broad spread vertical distribution pattern. The bulk of the population was centered in the 200 to 300 m layer in both regions in September.

\section{Percentage (\%)}
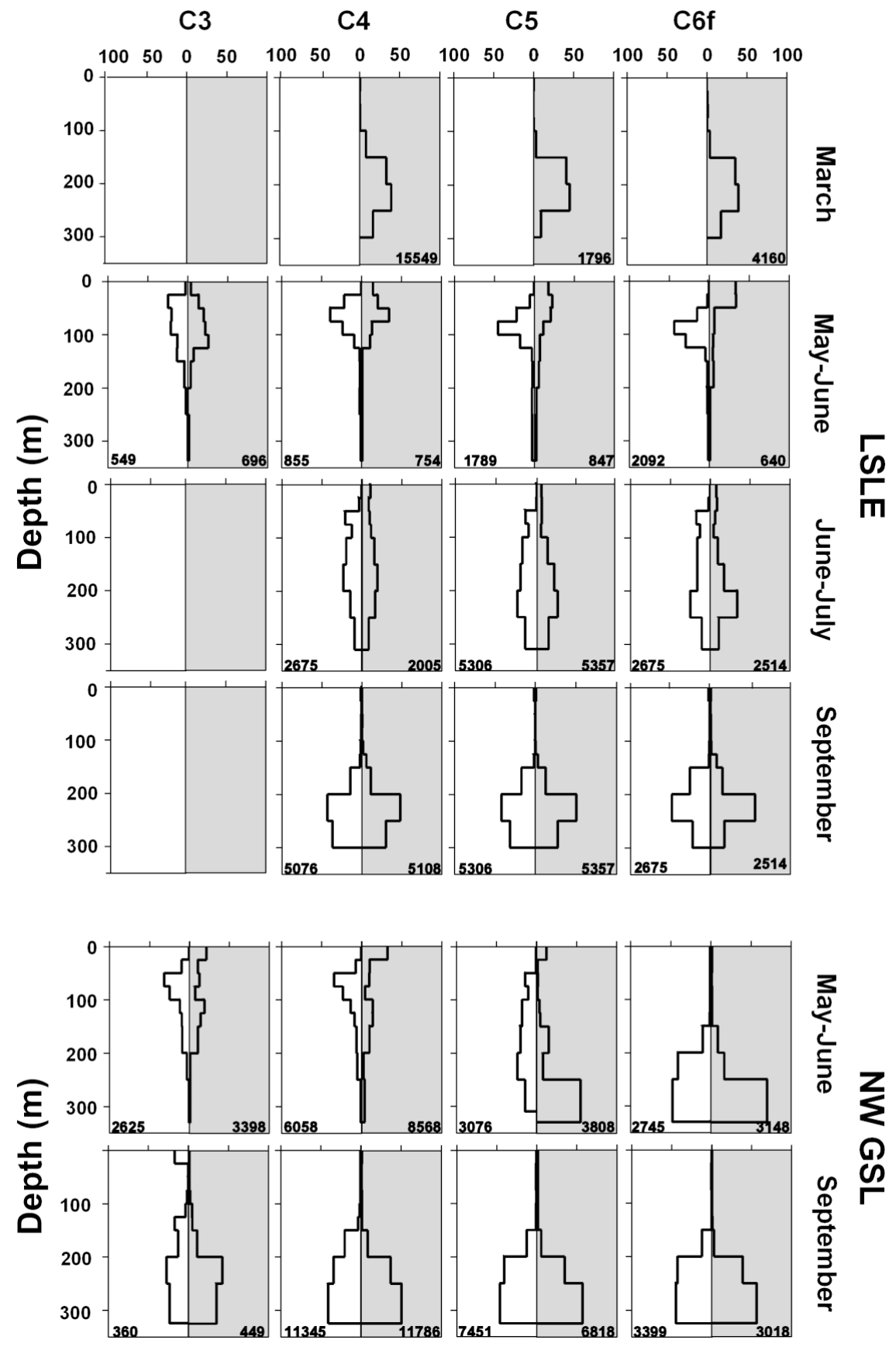

Fig. 6. Calanus hyperboreus. Day (open panels) and night (gray panels) vertical distribution of life stages during different periods of the year in the lower St. Lawrence Estuary (LSLE) and the NW Gulf of St. Lawrence (NW GSL). Numbers represent the mean integrated abundance (ind. $\mathrm{m}^{-2}$ ) of different development stages in 2 to 5 tows

\section{Gonad maturation and egg production}

Calanus hyperboreus Stage C6f collected between mid-April and mid-December had immature gonads. However, $12 \%$ of Stage C6f showed developed gonads in the sample collected for the egg production experiment on 18 December 1991 (Fig. 7A). Capture and laboratory manipulations apparently triggered the start of gonad maturation; C. hyperboreus Stage C6f caught in midOctober and incubated at $4.5^{\circ} \mathrm{C}$ in 1998 and 1999 started to mature 4 to $6 \mathrm{wk}$ earlier than in 1991. We therefore considered mid-December as more representative of the natural timing of the onset of the gonad maturation of $C$. hyperboreus Stage C6f in the LSLE. Temperature influenced the gonad maturation process as shown by the more rapid increase in the reproductive index at $8^{\circ} \mathrm{C}$ than at 0 and $4.5^{\circ} \mathrm{C}$ (ANCOVA, p < 0.05). However, food did not appear to affect the gonad maturation rate at $0^{\circ} \mathrm{C}$ (ANCOVA, $\mathrm{p}>$ 0.05) (Fig. 7A).

Food had no consistent effect on egg production. Egg production rate and clutch size in the FSW and fed treatments were similar during the first $40 \mathrm{~d}$ of the $0^{\circ} \mathrm{C}$ experiment (ANOVA, p > 0.05) (Fig. 7B,C). However, despite a relatively low number of observations, clutch size was significantly higher in the fed treatment during the last portion of the experiment (ANOVA, p < 0.001).

The lower range of temperatures did not affect the duration of spawning. The laboratory population laid eggs over roughly $100 \mathrm{~d}$ at $0^{\circ} \mathrm{C}$ (January to the end of March) and $4.5^{\circ} \mathrm{C}$ (late November to late February) (Fig. 7B). The experiment at $8^{\circ} \mathrm{C}$ was terminated before providing information on the spawning duration. According to the field observations of gonad maturation, we considered that the $0^{\circ} \mathrm{C}$ data best reflect the natural spawning period of the population. Stage C6f attained a maximum egg production rate $35 \mathrm{~d}$ after the start of gonad maturation, and maintained this high rate for $1 \mathrm{mo}$; egg production then ceased after a decreasing period of $6 \mathrm{wk}$ (Fig. 7B). The pat- 

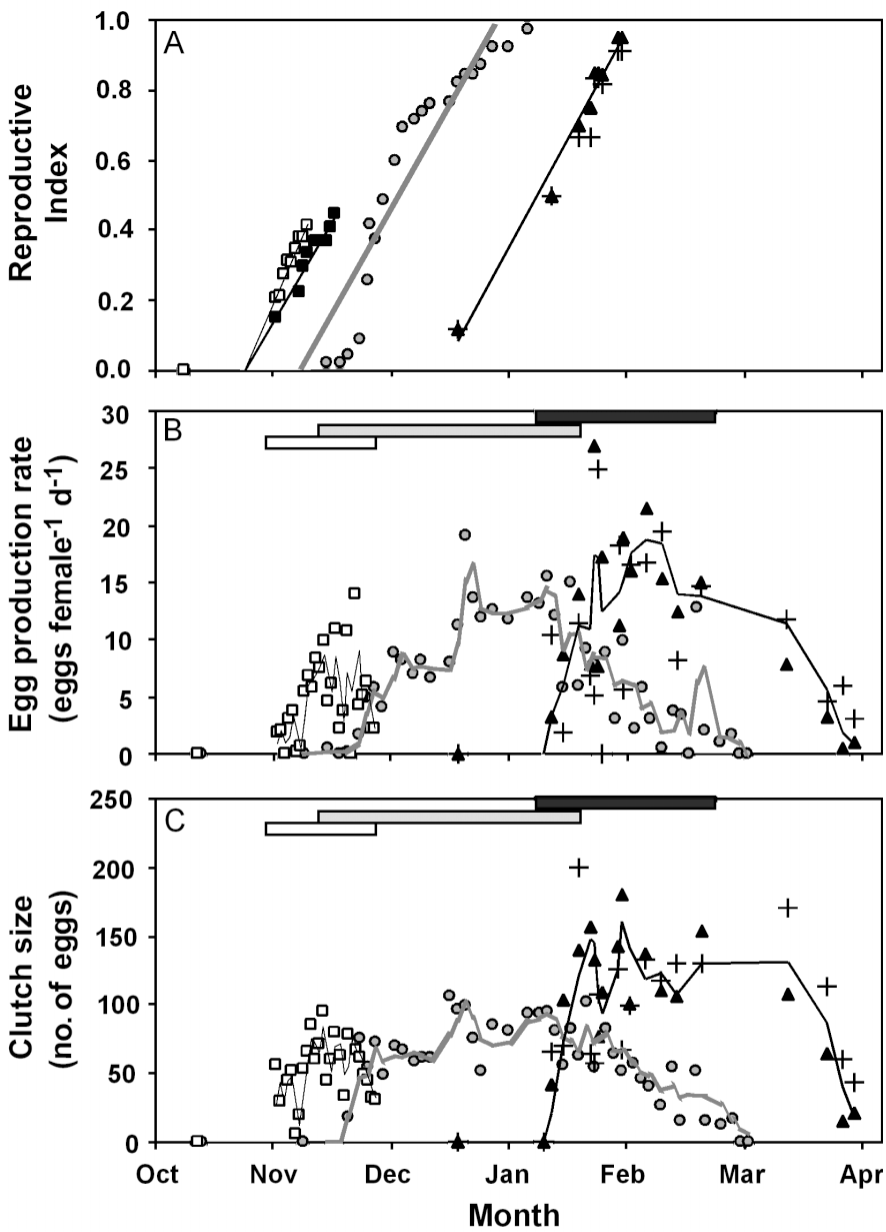

Fig. 7. Calanus hyperboreus. Reproduction of Stage C6f in the laboratory in filtered seawater (FSW) $(\mathbf{\Lambda})$ and enriched conditions (+) at $0^{\circ} \mathrm{C}$ in $1991-92$, in FSW at $4.5^{\circ} \mathrm{C}$ in 1998 (匹) and 1999 (•) and in FSW at $8^{\circ} \mathrm{C}$ in 1998 (). (A) Gonad maturation index as the proportion of mature Stage C6f. Index at time of capture for the experiment at 4.5 and $8^{\circ} \mathrm{C}$ was not included in the fitted linear regressions (equations not shown). (B) Egg production and $(\mathrm{C})$ average clutch size of the laboratory population. Bars denote the period considered in statistical analysis at 0 (filled), 4.5 (gray) and $8^{\circ} \mathrm{C}$ (open). Lines in $\mathrm{B}$ and $\mathrm{C}$ indicate 2 points running mean

\section{Energy budget and reproductive potential}

We used the 1999 experiment at $4.5^{\circ} \mathrm{C}$, in which the dry weight of 36 spent Stage C6f was measured, to describe the energy budget of Stage C6f during egg production. The initial body carbon mass ranged from 1493 to $2389 \mu \mathrm{g}$ (average of $1936 \mu \mathrm{g}$ ) and final body carbon mass from 204 to $905 \mu \mathrm{g}$ (average of $360 \mu \mathrm{g}$ ), representing a loss of $81 \%$. Total egg production varied from 251 to 1585 eggs female ${ }^{-1}$ (average of 762 eggs female ${ }^{-1}$ ) and respiration rate varied by a factor of 4 ( 5 to $20 \mu \mathrm{g} \mathrm{C}$ ind. ${ }^{-1} \mathrm{~d}^{-1}$ ). We used correlation matrices to show the relationship of total egg production (Table 2a) and respiration rate (Table 2b) (considered separately because they are not independent variables) with the initial body carbon, clutch size, number of clutches produced and spawning duration. Surprisingly, neither total egg production nor clutch size showed a significant relationship with the initial body carbon (Table 2a). However, total egg production was positively correlated to the size and number of clutches produced, the latter being positively related to spawning duration (Table 2a). Interestingly, the numbers of clutches and the spawning duration were negatively correlated to respiration rate (Table $2 b$ ).

Based on these results, we used a simple bioenergetic model to predict the potential effect of temperature on the reproduction of Calanus hyperboreus collected in autumn 1999. For each temperature tested $(0$, 4.5 and $8^{\circ} \mathrm{C}$ ), the total body carbon loss (individual initial body carbon-average final body carbon) was divided by the daily body carbon loss (respiration rate + egg production rate) to calculate the spawning duration. We adjusted the mean respiration rate estimated at $4.5^{\circ} \mathrm{C}\left(10.7 \mu \mathrm{g} \mathrm{C}\right.$ ind..$\left.^{-1} \mathrm{~d}^{-1}\right)$ to $0^{\circ} \mathrm{C}\left(6.4 \mu \mathrm{g} \mathrm{C}\right.$ ind..$\left.^{-1} \mathrm{~d}^{-1}\right)$ and $8^{\circ} \mathrm{C}\left(17.1 \mu \mathrm{g} \mathrm{C}\right.$ ind. $\left.{ }^{-1} \mathrm{~d}^{-1}\right)$ according to Conover \& Corner (1968) and Hirche (1987). We estimated a daily body carbon loss due to egg production rate of 14.2, 11.2 and $12.9 \mu \mathrm{g} \mathrm{C}$ ind.$^{-1} \mathrm{~d}^{-1}$ at $0,4.5$ and $8^{\circ} \mathrm{C}$, respectively (Table 1). Finally, the spawning duration and the tern of clutch size closely followed that of egg production rate (Fig. $7 \mathrm{C}$ ). We combined the results from Stage C6f that laid 3 or more clutches in different experiments to test the effect of temperature on key reproduction parameters. The spawning interval, clutch size and egg production rate significantly decreased with increasing temperature whereas the mean individual spawning duration was similar at 0 and $4.5^{\circ} \mathrm{C}$ (Table 1). On average, Calanus hyperboreus Stage C6f produced a similar number of eggs at 0 and $4.5^{\circ} \mathrm{C}$ (Table 1$)$.
Table 1. Calanus hyperboreus. Egg production experiment. Comparison of parameters during corresponding periods in experiments at different temperatures

\begin{tabular}{|c|c|c|c|c|}
\hline \multirow[b]{2}{*}{ Variable } & \multicolumn{3}{|c|}{ Experiment } & \multirow{2}{*}{$\mathrm{p}$} \\
\hline & 1991-92 & 1998 & 1999 & \\
\hline Period considered (d) & 46 & 26 & 72 & \\
\hline Temperature $\left({ }^{\circ} \mathrm{C}\right)$ & $0-1$ & 8 & 4.5 & \\
\hline Mean clutch size (no. of eggs) & 125.3 & 58.9 & 75.4 & 0.0001 \\
\hline Spawning interval (d) & 7.3 & 3.8 & 5.6 & 0.0001 \\
\hline $\begin{array}{l}\text { Mean egg production rate } \\
\left(\text { eggs female }{ }^{-1} \mathrm{~d}^{-1}\right)\end{array}$ & 11.9 & 4.7 & 8.4 & 0.0001 \\
\hline Individual spawning duration (d) & 50 & - & 46 & $>0.05$ \\
\hline Total fecundity (eggs female ${ }^{-1}$ ) & 724 & - & 762 & $>0.05$ \\
\hline
\end{tabular}


Table 2. Calanus hyperboreus. Correlation matrix of (a) total egg production and (b) estimated respiration rate with key parameters of $C$. hyperboreus reproduction. Significant correlations $(\mathrm{p}<0.05)$ indicated in bold

\begin{tabular}{|c|c|c|c|c|c|}
\hline (a) Variable & Total egg production & Body carbon & Mean clutch size & Number clutch & Log spawning duration \\
\hline Total egg production & 1.000 & 0.271 & 0.745 & 0.489 & 0.335 \\
\hline Body carbon & 0.271 & 1.000 & 0.217 & 0.101 & 0.284 \\
\hline Mean clutch size & 0.745 & 0.217 & 1.000 & -0.166 & -0.222 \\
\hline Number clutch & 0.489 & 0.101 & -0.166 & 1.000 & 0.831 \\
\hline Log spawning duration & 0.335 & 0.284 & -0.222 & 0.831 & 1.000 \\
\hline (b) Variable & Respiration rate & Body carbon & Mean clutch size & Number clutch & Log spawning duration \\
\hline Respiration rate & 1.000 & -0.161 & -0.267 & -0.529 & -0.475 \\
\hline Body carbon & -0.161 & 1.000 & 0.205 & 0.125 & 0.358 \\
\hline Mean clutch size & -0.267 & 0.205 & 1.000 & -0.155 & -0.203 \\
\hline Number clutch & -0.529 & 0.125 & -0.155 & 1.000 & 0.839 \\
\hline Log spawning duration & -0.475 & 0.358 & -0.203 & 0.839 & 1.000 \\
\hline
\end{tabular}

observed egg production rate were used to calculate the potential total egg production (Table 1). Based on this simple model, the temperature during the overwintering period may affect the duration and amplitude of reproduction in C. hyperboreus (Fig. 8). On average, the daily body carbon loss was higher at $8^{\circ} \mathrm{C}$ than at 0 and $4.5^{\circ} \mathrm{C}$, resulting in a significant reduction $(33 \%)$ in predicted spawning duration (Fig. 8A,B). The interplay between respiration rate, clutch size, spawning interval and spawning duration resulted in a significant decrease in total egg production at a higher temperature (Fig. 8C).

The reproductive potential of the Calanus hyperboreus population in the LSLE varied significantly among years. This difference was caused by the 2- to 4 -fold variations in the abundance of adult females, as the individual reproductive potential was similar due to relatively constant female body size and temperature in the 200 to $250 \mathrm{~m}$ water layer (Fig. 9A,B). However, there was no obvious correspondence between the maximal abundance of Stage C1 to C3 in May and June and the potential reproductive output of the population (Fig. 9B).

\section{DISCUSSION}

Our results support the general hypothesis that the life cycle of Calanus hyperboreus is not adapted to the environmental conditions in the LSLE. We suggest instead that the population is maintained by advection from adjacent regions and therefore that the LSLE C. hyperboreus represent an extension of the GSL population. Here, we discuss different aspects of the life cycle of this arctic species, in relation to the general knowledge of its biology and to the environmental conditions in the LSLE-GSL region.
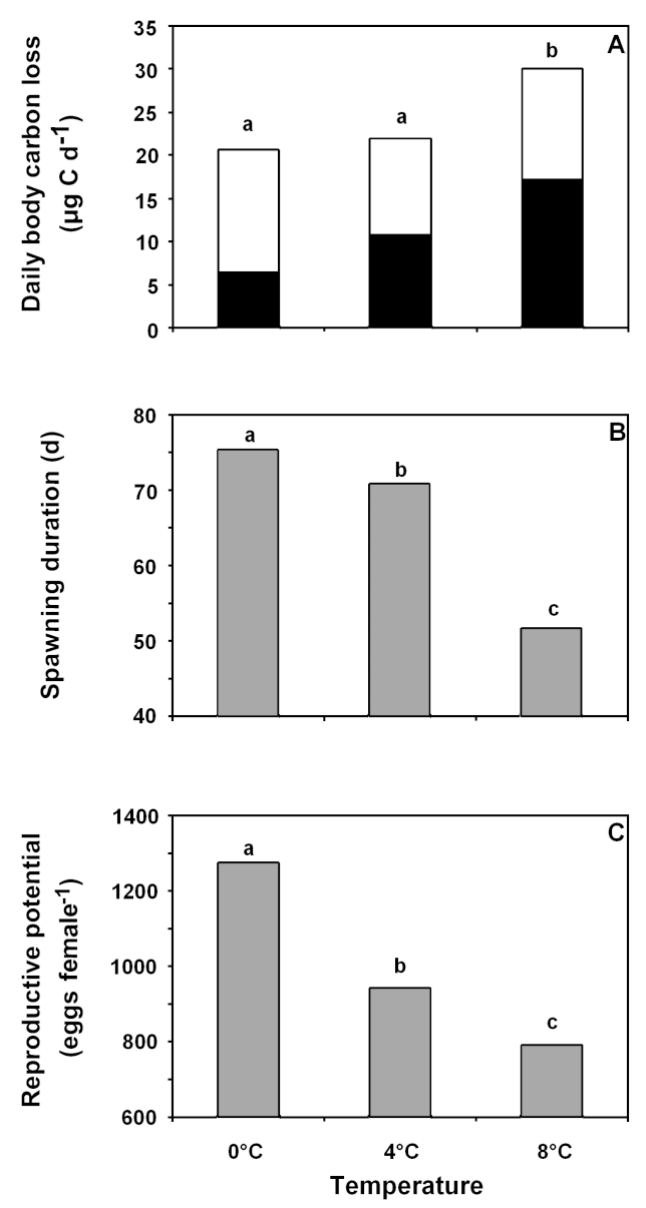

Fig. 8. Calanus hyperboreus. Predicted individual reproductive potential of Stage C6f in the lower St. Lawrence Estuary (LSLE) in autumn. (A) Daily body carbon loss $\left(\mu \mathrm{g} \mathrm{C} \mathrm{d}^{-1}\right)$ due to respiration (black) and egg production (white), (B) spawning duration, and (C) estimated individual total egg production (eggs female ${ }^{-1}$ ). Letters denote significant statistical differences 


\section{Duration and timing of the life cycle}

The reproduction of Calanus hyperboreus occurred early relative to the late onset of the phytoplankton bloom (late June) in the LSLE. The spawning from late December to late March in the LSLE closely matched the reproductive pattern observed in the Gulf of Maine, a region where the spring phytoplankton bloom typically starts in April (Conover \& Corner 1968). C. hyperboreus reproduces from November to late March in the ice-free Greenland Sea, January and May in the central Arctic Ocean, and from March to June in the Canadian Arctic; differences are thought to reflect the local timing of the phytoplankton bloom (Conover \& Siferd 1993, Hirche \& Neihoff 1996). Considering that the phytoplankton bloom in the LSLE typically begins in late June, a reproductive period
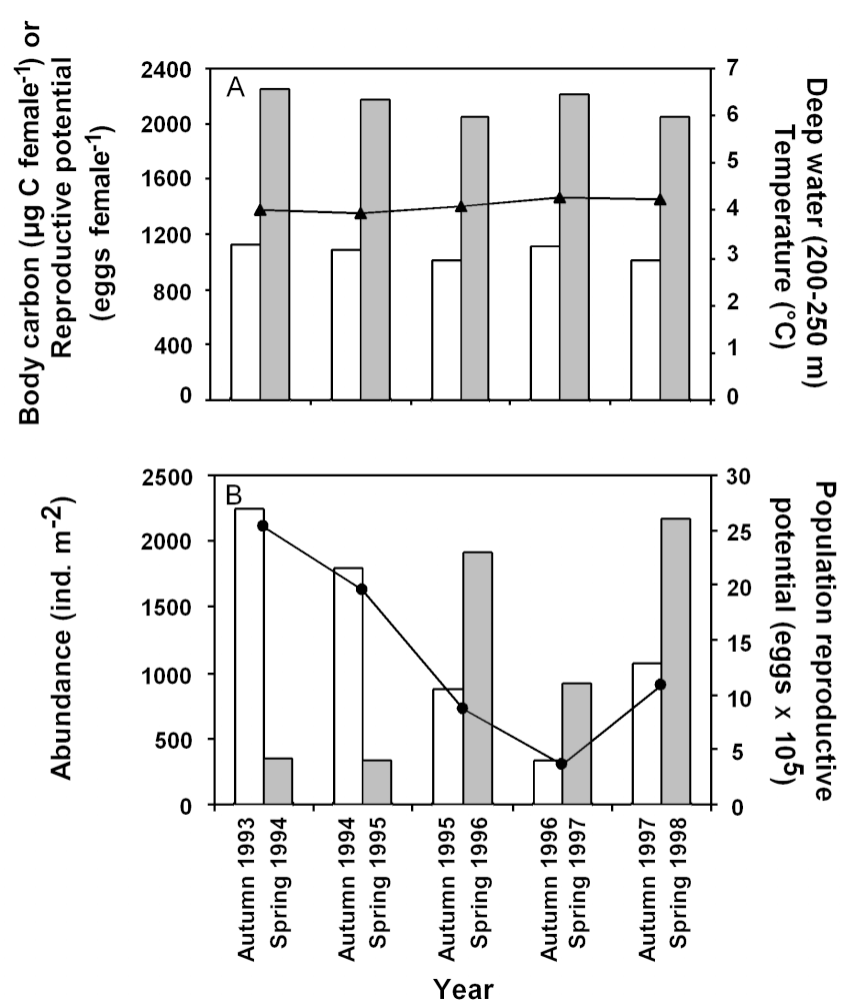

Fig. 9. Calanus hyperboreus. Relationship between individual reproductive potential of Stage C6f and population reproductive potential (autumn 1993 to 1997) with maximum abundance of copepodid Stages C1 to C3 in the following May and June (1994 to 1998) in the lower St. Lawrence Estuary (LSLE). (A) Mean Stage C6f body-carbon weight ( $\mu \mathrm{g} \mathrm{C}$ female ${ }^{-1}$ ) (gray bars), individual reproductive potential (white bars) and average temperature in the 200 to $250 \mathrm{~m}$ depth (A) at the monitoring station during the main and post-bloom period. (B) Mean Stage C6f abundance (ind. $\mathrm{m}^{-2}$ ) (white bars), population reproductive potential (eggs $\mathrm{m}^{-2}$ ) in autumn (0) and maximum abundance of Stages C1 to C3 during the May-June period of the following year (gray bars). Population reproductive potential is given as $\times 10^{5}$ extending from March to May would have been expected in the region. Apparently, the reproduction of the C. hyperboreus population was not adapted to the seasonal pattern in phytoplankton biomass in the LSLE.

The development of the early stages of Calanus hyperboreus appeared independent of the phytoplankton bloom in the LSLE. C. hyperboreus eggs and nauplii contain high lipid reserves used to support development to the first feeding stage during migration to the surface, and to 'buffer' the lag time between spawning and the onset of the phytoplankton bloom (Conover 1988). Moreover, mounting evidence indicates that naupliar stages of large marine calanoid copepods achieve high growth rates at food levels $\left(50 \mu \mathrm{g} \mathrm{C}^{-1}\right)$ corresponding to the average chl a biomass $\left(30 \mathrm{mg} \mathrm{m}^{-2}\right.$ ) observed during the pre-bloom period in the LSLE, implying a lower susceptibility to food-limited development than in the late copepodid stages (Richardson \& Verheye 1999, Hygum et al. 2000). The low surface and mid-water temperatures during the winter-spring period apparently governed the development of the early stages of $C$. hyperboreus in the LSLE, and may explain the 1 mo delay in the occurrence of the peak in abundance of the early copepodid Stages C1 to C4 relative to the warmer Gulf of Maine. On the other hand, the low phytoplankton biomass in spring appears to have limited the growth of late copepodid stages in the LSLE. While the body weight of Stages C4, C5 and C6f was at a minimum in early April in both regions, the gain in body weight in these stages corresponded to the phytoplankton bloom in the Gulf of Maine (late April) and the LSLE (midJune) (Conover \& Corner 1968). The late development in the LSLE appeared to cascade through the life history, and delayed entry into diapause of the late copepodids. The seasonal patterns in vertical distribution, body weight and abundance of Stages C4, C5 and C6f suggested that the $C$. hyperboreus population underwent its ontogenetic downward migration in late June-early July in the LSLE, 1 mo later than in the NW GSL, Gulf of Maine and in the deep basins of the Scotian Shelf (Conover \& Corner 1968, Sameoto \& Herman 1990).

These results indicate a 2 to 3 yr life cycle for Calanus hyperboreus in the LSLE-GSL. A 1 yr life cycle has been described for C. hyperboreus in the warmer Gulf of Maine (Conover 1988). The presence of Stages C4, $\mathrm{C} 5$ and $\mathrm{C} 6$ in the overwintering population of Calanus spp. indicates a multiyear life cycle (Conover 1988). The large size of $C$. hyperboreus Stage C6f also indicates a life span $>1 \mathrm{yr}$, and the potential for iteroparity. In the sub-arctic Pacific, Neocalanus spp. maintains a 'true' 1 yr life cycle with a reproductive strategy similar to C. hyperboreus: Stage C6f moult from Stage C5, re- 
production and death during the overwintering period, with the consequence that they never feed in surface layer and their body size never exceeds that of Stage C5 (Conover 1988, Miller et al. 1992). If C. hyperboreus Stage C6f recruits from the local Stage C5 stock, and does not feed during the overwintering period, it is unlikely that Stage C6f of the year would be heavier than Stage C5. We infer that the majority of Stage C6f smaller than $3000 \mu \mathrm{g}$ were newly moulted individuals and that larger C6f in the LSLE (1) had previously fed and accumulated body reserves, (2) were in their second overwintering period, and (3) were potentially iteroparous. After a year passed as juveniles, C. hyperboreus Stage C6f appeared to live $2 \mathrm{yr}$, with the main reproductive effort during their second winter. A substantial proportion of C. hyperboreus Stage C6f are larger relative to Stage C5 across the geographic range of C. hyperboreus, suggesting iteroparity as a general life-cycle trait (Conover \& Corner 1968, Conover \& Siferd 1993, Hirche 1997).

\section{Egg production and reproductive potential}

Food had no obvious strong effect on the egg production of Calanus hyperboreus. The decrease in dry weight in Stages C4, C5 and C6f during overwintering and reproduction suggests either the inability to feed due to reduced mouth parts or to the absence of external food sources, or both (Conover \& Corner 1968). However, the larger clutches produced by fed Stage C6f toward the end of our laboratory experiments do suggest a potential for active feeding associated with the ontogenetic vertical ascent and the potential for an increase in egg production at the end of the reproductive period (Conover \& Siferd 1993, Hirche 1997). However, this process appeared unlikely to occur in the LSLE considering the late onset of the phytoplankton bloom and the food-limited growth in late copepodid stages evidenced during spring in the region.

We did not find the anticipated positive relationship between fecundity and body size in Calanus hyperboreus Stage C6f. We formulated this hypothesis on the basis that $C$. hyperboreus Stage C6f sustain egg production from their body reserves, and on the positive relationship observed between clutch size and prosome length in C. finmarchicus and C. glacialis (Hirche 1989, Runge \& Plourde 1996, Hirche et al. 1997). The mean respiration rate and its large individual variation (4-fold) estimated in our experiment corresponded to direct measurement of respiration made during overwintering in Calanus spp. (Conover \& Corner 1968, Ingvarsdottir et al. 1999). Our simple energy budget indicates that respiration rate mainly determines the individual daily body carbon expenditure, spawning duration and consequently total fecundity. The inverse relationship observed between spawning interval and temperature in $C$. finmarchicus and C. glacialis results in a higher egg production rate, as clutch size is independent of temperature (Hirche 1989, Hirche et al. 1997). The contrasting decrease in clutch size and egg production rate of C. hyperboreus with temperature was unexpected and suggests a different strategy of energy allocation in species producing eggs from their body reserves.

\section{General effect of estuarine circulation}

The decrease in total abundance of Calanus hyperboreus observed in the LSLE from April to early June likely resulted from the interplay between the timing of reproduction and the ontogenetic ascent to surface, and the timing of the period of maximum freshwater runoff (April to June). The eggs produced during the main part of the reproduction period (February) would have taken 70 to $80 \mathrm{~d}$ to develop into surface-dwelling Stages $\mathrm{C} 1$ to $\mathrm{C} 3$ at temperatures $\left(-1\right.$ to $\left.1^{\circ} \mathrm{C}\right)$ typical of the surface and mid-water layers in winter-spring, which would have favored their massive export during the period of high freshwater discharge and low residence time of the surface water (12 to $15 \mathrm{~d}$ ) in the region (Corkett et al. 1986, Zakardjian et al. 1999). Based on the same laboratory-derived development times, Stages C1 to C3 observed from mid-May to midJune in some years have likely developed from eggs produced in late March, which supports the contention that the main part of the local reproductive output did not contribute to recruitment in the LSLE. The ontogenetic ascent to the surface in copepodid Stages C4, C5 and C6f in April-May after their overwintering period, and their vertical migration within the surface 0 to $50 \mathrm{~m}$ at night in late May-early June suggest that their abundance was also greatly diminished by the strong surface outflow in late spring. The delayed ontogenetic downward migration after the lipid build-up in Stages C4, C5 and C6f caused by the food-limited development and growth during the pre-bloom period likely favored their transport in the surface outflow. A modeling study of the interaction between vertical migration of zooplankton and a schematic estuarine 2-layer flow field showed that the abundance of a diel vertical migrant ( 25 to $150 \mathrm{~m}$ ) would be reduced by $70 \%$ within $20 \mathrm{~d}$ at residual velocities typical of the LSLE in spring (Zakardjian et al. 1999).

We hypothesize that the increase in abundance of Calanus hyperboreus in late June-early July mainly reflects the interaction between the earlier development and ontogenetic downward migration of the population in the NW GSL and immigration in the deep 
upstream component of the estuarine 2-layer circulation. Local recruitment should not have contributed to this process as the early Stages C1 to C3 occurred during the period of the abrupt decrease in the total abundance of the population in April to mid-June. The upstream currents in the sub-surface layers peak during late spring and early summer, in response to the maximum surface freshwater runoff (Tee \& Lim 1987, Bourgault 2001). Simulation in a schematic representation of a 2-layer flow field showing upstream deepwater currents of 5 to $10 \mathrm{~cm} \mathrm{~s}^{-1}$ revealed that animals located at 75 (CIL) and $175 \mathrm{~m}$ (deep layer) accumulated $200 \mathrm{~km}$ upstream within 20 to $40 \mathrm{~d}$ (Zakardjian et al. 1999). Assuming that the late development stages of C. hyperboreus migrated to deep water for overwintering in late May in the NW GSL, this advection time would explain the presence of the overwintering latedevelopment stages issued from the NW GSL in central LSLE in early summer. Such timing roughly corresponds to the increase in total abundance and body weight in late copepodid stages, stable population stage-structure and deep vertical distribution of a large portion of the C. hyperboreus population observed in late June and early July in the LSLE.

\section{Interannual variations}

Our egg production experiments showed that the variations in temperature recorded in the overwintering habitat of Calanus hyperboreus in the LSLE-GSL (3 to $7^{\circ} \mathrm{C}$ : Budgen 1991) might significantly affect the duration of the spawning period and the total fecundity. The spawning duration of $C$. hyperboreus may be shortened by 25 to $30 \mathrm{~d}$, and reproductive output reduced by $30 \%$ under warmer conditions. Considering that interannual and interdecadal variations in temperature in deep water are uncoupled with those in the CIL and in the surface layer (Gilbert \& Pettigrew 1997), the change in duration of reproduction may lead to significant changes in the timing of the occurrence of feeding stages in the surface layer in regard to (1) timing of onset of the phytoplankton bloom in the NW GSL, and (2) timing of maximal freshwater discharge in the LSLE. Therefore, such temperature-dependent variations in the dynamics of reproduction may have important impacts on the recruitment of C. hyperboreus. Clearly, energy allocation during overwintering and reproduction at different temperatures merits future research in order to understand a mechanism that may limit the southward distribution of C. hyperboreus in the north Atlantic.

The lack of correspondence between years of high reproductive potential of the population, the abundance of Stage C1 to C3 in spring, and the constant timing of the spawning period driven by the conditions of the overwintering habitat of Calanus hyperboreus suggest that other mechanisms are implicated in the control of abundance of these early copepodid stages in the LSLE. Given that only the eggs produced towards the end of the spawning season likely contributed to local recruitment, we believe that the C. hyperboreus population is very sensitive to variations in timing and amplitude of the maximum freshwater runoff in spring, which would explain interannual variations in abundance of Stages C1 to C3 observed in the LSLE over the studied period. Buoyancy has been identified as the main factor controlling the general circulation pattern in summer in the LSLE (Ingram \& El-Sabh 1990). Although interannual variations in the timing and intensity of the freshwater runoff in April, May and June have been observed, we do not know how the surface circulation in the LSLE would respond to these variations. Clearly, more studies on circulation in the LSLE in winter and spring are needed in order to understand the interaction between circulation and the life cycle of $C$. hyperboreus in the region.

Assuming that the main part of the overwintering Calanus hyperboreus in the LSLE originated from the NW GSL, we propose that variations in the population dynamics of C. hyperboreus in this region were for the most part responsible for interannual differences observed in the stage structure of the population in the LSLE. In a 2 yr life cycle, a low annual recruitment would result in a decrease in Stage C4 abundance, as most of these stages are believed to moult to Stage C5 in late winter-early spring (Hirche 1997). However, very low abundance of Stage C4 in the overwintering population followed autumns of contrasting population reproductive potential. A year of high (or low) C5 may simply reflect a faster (or slower) development of the younger stages. Important interannual and interdecadal variations in ice cover, temperature $\left(3\right.$ to $\left.4^{\circ} \mathrm{C}\right)$ and timing and amplitude of the phytoplankton bloom ( 2 to $4 \mathrm{wk}$ ) in the NW GSL may potentially favor a more rapid development of the new cohort, resulting in a more predominant 1 yr life cycle (Conover 1988, Koutitonsky \& Budgen 1991, Fuentes-Yaco et al. 1997). The lack of knowledge of variability in upper-layer temperature and phytoplankton bloom dynamics in the NW GSL during the winter-spring transition over the study hinders further inference about the environmental control of C. hyperboreus population development and recruitment in the region.

Mortality remains a key unresolved issue in the control of the demography of marine copepods. The LSLE-GSL region sustains large stocks of euphausiids, mysiids and pelagic fishes, all known to be important predators on Calanus spp. (Runge \& Simard 1990). Additionally, changes in the copepod community 
structure may have modified the top-down control of recruitment in C. hyperboreus. A decrease in C. hyperboreus abundance between 1979-80 and 1994-98 has been accompanied by a 10 -fold increase in abundance of Metridia longa, an arctic species known to feed on eggs and nauplii of C. hyperboreus and other zooplankton species (Conover \& Huntley 1991, Plourde et al. 2002). Knowledge of the interannual variability in predator stock would contribute to the understanding of C. hyperboreus (and zooplankton) demography in the region.

We conclude that the interaction between the life cycle strategy of Calanus hyperboreus and the seasonal circulation pattern favors massive export of the locally produced cohort by strong surface outflow in late spring and deep advection of the overwintering population from the adjacent NW GSL in summer. Although local recruitment occurred in some years, there is no indication of a stable life cycle synchronized with the seasonal phytoplankton cycle in the LSLE. This represents a departure from the dynamics of C. finmarchicus in the region, which shows reproduction of a large portion of the population in response to the phytoplankton bloom in late June, and development of the cohort in July and August (Plourde et al. 2001). Moreover, large interannual and interdecadal variations in the deep-water temperature may induce important changes in duration, timing and amplitude of the reproduction of $C$. hyperboreus in the region.

Acknowledgements. We thank L. Chénard and M. Ringuette for their support at sea and in the laboratory as well as D. Gilbert for RIVSUM data. This research was supported by Fisheries and Oceans Canada, Laurentian Region, and by grants from the Natural Sciences and Engineering Research Council (NSERC) to J.J.D. and to J.A.R. through the Global Ocean Ecosystem Dynamics program (GLOBEC Canada). S.P. was funded by NSERC (Canada), Fonds pour la formation de Chercheurs et l'Aide à la Recherche, Québec (FCAR) and GIROQ (Groupe Interuniversitaire de Recherches Océanographiques du Québec) fellowships. This is a contribution to the program of GIROQ.

\section{LITERATURE CITED}

Bourgault D (2001) Circulation and mixing in the St. Lawrence Estuary. PhD thesis, McGill University, Montréal

Bugden GL (1991) Changes in temperature-salinity characteristics of the deeper waters of the Gulf of St. Lawrence over the past several decades. In: Therriault JC (ed) The Gulf of St-Lawrence: small ocean or big estuary? Can Spec Publ Fish Aquat Sci 113:139-147

Budgen GL, Hargrave BT, Sinclair MM, Tang CL, Therriault JC, Yeats PA (1982) Freshwater runoff effects in the marine environment: the Gulf of St. Lawrence example. Can Tech Rep Fish Aquat Sci 1078

Conover RJ (1988) Comparative life histories in the genera Calanus and Neocalanus in high latitudes of the northern hemisphere. Hydrobiologia 167/168:127-142
Conover RJ, Corner EDS (1968) Respiration and nitrogen excretion by some marine zooplankton in relation to their life cycles. J Mar Biol Assoc UK 48:49-75

Conover RJ, Huntley M (1991) Copepods in ice-covered seas - distribution, adaptations to seasonally limited food, metabolism, growth patterns and life cycle strategies in polar seas. J Mar Syst 2:1-41

Conover RJ, Siferd TD (1993) Dark-season survival strategies of coastal zone zooplankton in the Canadian Arctic. Arctic 46:303-311

Corkett CJ, McLaren IA, Sevigny JM (1986) The rearing of the marine calanoid copepods Calanus finmarchicus (Gunnerus), C. glacialis Jaschnov and C. hyperboreus Kroyer with comment on the equiproportional rule. Syllogeus 58:539-546

de Lafontaine Y, Demers S, Runge J (1991) Pelagic food web interactions and productivity in the Gulf of St. Lawrence: a perspective. In: Therriault JC (ed) The Gulf of St. Lawrence: small ocean or big estuary? Can Spec Publ Fish Aquat Sci 113:99-123

El-Sabh MI (1979) The Lower St. Lawrence Estuary as a physical oceanographic system. Nat Can 106:55-73

Fuentes-Yaco C, Vézina AF, Larouche P, Vigneau C, Gosselin M, Levasseur M (1997) Phytoplankton pigment in the Gulf of St. Lawrence, Canada, as determined by the coastal zone color scanner. Part I. Spatio-temporal variability. Cont Shelf Res 17:1421-1439

Gilbert D, Pettigrew B (1997) Interannual variability (19481994) of the CIL core temperature in the Gulf of St. Lawrence. Can J Fish Aquat Sci 54:57-67

Hirche HJ (1987) Temperature and plankton. 2. Effect on respiration and swimming activity in copepods from the Greenland Sea. Mar Biol 94:347-356

Hirche HJ (1989) Egg production of the Arctic copepod Calanus glacialis: laboratory experiments. Mar Biol 103: $311-318$

Hirche HJ (1997) Life cycle of the copepod Calanus hyperboreus in the Greenland Sea. Mar Biol 128:607-618

Hirche HJ, Niehoff B (1996) Reproduction of the Arctic copepod Calanus hyperboreus in the Greenland Sea: field and laboratory observations. Polar Biol 3:209-219

Hirche HJ, Meyer U, Niehoff B (1997) Egg production of Calanus finmarchicus: effect of temperature, food and season. Mar Biol 127:609-620

Huntley ME, Lopez MDG (1992) Temperature-dependent production of marine copepods: a global synthesis. Am Nat 140:201-242

Hygum BH, Rey C, Hansen BW (2000) Growth and development rates of Calanus finmarchicus nauplii during a diatom spring bloom. Mar Biol 136:1075-1086

Ingram RG, El-Sabh MI (1990) Fronts and mesoscale features in the St. Lawrence Estuary. In: El-Sabh MI, Silverberg $\mathrm{N}$ (eds) Coastal and estuarine studies: oceanography of a large-scale estuarine system-the St. Lawrence. Springer-Verlag, New York, p 71-93

Ingvarsdottir A, Houlihan DF, Heath MR, Hay SJ (1999) Seasonal changes in respiration rates of copepodid stage $\mathrm{V}$ Calanus finmarchicus (Gunnerus). Fish Oceanogr 8:73-83

Koutitonsky VG, Budgen GL (1991) The physical oceanography of the Gulf of St. Lawrence: a review with emphasis on the synoptic variability of the motion. In: Therriault JC (ed) The Gulf of St. Lawrence: small ocean or big estuary? Can Spec Publ Fish Aquat Sci 113:57-90

Loder JW, Petrie B, Gawarkiewicz G (1998) The coastal ocean off northeastern north America: a large scale view. In: Robinson AR, Brink KH (eds) The sea, Vol 11. John Wiley \& Sons, New York, p 105-133 
Miller CB, Fulton J, Frost BW (1992) Size variation of Neocalanus plumchrus and Neocalanus flemingeri in a $20 \mathrm{yr}$ sample series from the Gulf of Alaska. Can J Fish Aquat Sci 49:389-399

Parson TR, Maita Y, Lalli CM (1984) A manual of chemical and biological methods for seawater analysis. Pergamon Press, Oxford

Plourde S, Joly P, Runge JA, Zakardjian B, Dodson JJ (2001) Life cycle of Calanus finmarchicus in the lower St. Lawrence Estuary: the imprint of circulation and late timing of the spring phytoplankton bloom. Can J Fish Aquat Sci 58:647-658

Plourde S, Dodson J, Runge JA, Therriault JC (2002) Spatial and temporal variations in copepod community structure in the lower St. Lawrence Estuary, Canada. Mar Ecol Prog Ser 230:211-224

Richardson AJ, Verheye HM (1999) Growth rates of copepods in the southern Benguela upwelling system: the interplay between body size and food. Limnol Oceanogr 44: 382-392

Runge JA, Plourde S (1996) Fecundity characteristics of Calanus finmarchicus in coastal waters of eastern Canada. Ophelia 44:171-187

Runge JA, Simard Y (1990) Zooplankton of the St. Lawrence Estuary: the imprint of physical processes on its composition and distribution. In: El-Sabh MI, Silverberg N (eds) Coastal and estuarine studies: oceanography of a large-

Editorial responsibility: Howard Browman (Contributing Editor), Storebø, Norway scale estuarine system-the St. Lawrence. SpringerVerlag, New York, p 298-320

Sameoto DD, Herman AW (1990) Life cycle and distribution of Calanus finmarchicus in deep basins on the Nova Scotia shelf and seasonal changes in Calanus spp. Mar Ecol Prog Ser 66:225-237

Tee KT, Lim TH (1987) The freshwater pulse - a numerical model with application to the St. Lawrence Estuary. J Mar Res 45:871-909

Therriault JC, Levasseur M (1985) Control of phytoplankton production in the lower St. Lawrence Estuary: light and freshwater runoff. Nat Can 112:77-96

Unstad KH, Tande KS (1991) Depth distribution of Calanus finmarchicus and C. glacialis in relation to environmental conditions in the Barents Sea. In: Sakshaug E, Hopkins CCE, Øristland NA (eds) Proc Pro Mare Symp Polar Mar Ecol, Trondheim, 12-16 May 1990. Polar Res 10:409-420

Zakardjian BA, Runge JA, Plourde S, Gratton Y (1999) A biophysical model of the interaction between vertical migration of crustacean zooplankton and circulation in the Lower St. Lawrence Estuary. Can J Fish Aquat Sci 56: 2420-2432

Zakardjian BA, Gratton Y, Vezina AF (2000) Late spring phytoplankton bloom in the Lower St. Lawrence Estuary: the flushing hypothesis revisited. Mar Ecol Prog Ser 192: $31-48$

Submitted: July 27, 2002; Accepted: February 4, 2003

Proofs received from author(s): May 2, 2003 